\title{
Environmental Issues and the Greenhouse Effects in Nigeria: The Church's Approach
}

\author{
Obasola Kehinde Emmanuel ${ }^{1}$ \\ ${ }^{1}$ Department of Religious Studies, Olabisi Onabanjo University, Ago-Iwoye, Nigeria \\ Correspondence: Obasola Kehinde Emmanuel, Department of Religious Studies, Olabisi Onabanjo University, \\ Ago-Iwoye, Ogun State, Nigeria. Tel: 234-8037-268-917. E-mail:blessnuel@yahoo.com
}

\author{
Received: May 24, 2013 Accepted: August 21, 2013 Online Published: August 27, 2013 \\ doi:10.5539/res.v5n4p155 URL: http://dx.doi.org/10.5539/res.v5n4p155
}

\begin{abstract}
There is no doubt that the environment is witnessing a tremendous change due to several factors which have encumbered human society. Modern technology has brought in its wake several challenges which also inhibit the process of growth and development of mankind. Thus, one of the major discussions among contemporary scholars is the issue of global warming especially, in the recent times. It is both economically, in the politically important because of its effects and implications on humanity. In fact, this is the reason why governments all over the world are taking frantic efforts to mobilize both human and material resources so as to address this important issue.

There has been a serious degree of abuse of nature by human beings all over the world. This abuse has posed serious challenged to human life and existence. It has also posed a serious threat to the integrity of the whole creation and peace on earth. This is the reason why scholars, particularly, theologians and scientists have taken keen interest in addressing the issue of ecological and environmental crises with its attendant greenhouse effects with the view to nipping their effects on humanity. Therefore, this paper addresses the spiraling effects of the environmental crises in Nigeria as well as the greenhouse debacle from the religo-scientific perspectives. The paper posited that religion also has a role to play in this matter.
\end{abstract}

Keywords: environment, greenhouse effect, pollution, ecosystem, church

\section{Introduction}

Abogunrin (2009:1) posited that "one of the major concerns for humanity for early forty years has been how to deal with environmental crises threatening not only the continued existence of man, but our own very planet". This has been a major challenge that modern man is faced with at present. In fact, the whole world is engulfed in these environmental crises to the intent that life expectancy in most nations has been drastically and negatively affected.

It may be interesting to note that the state of our environmental crises has been catastrophic to the intent that Peacocke (1993: ix) remarked that:

No one today can contemplate the state of the late twentieth century humanity on this planet earth without a sense of deep foreboding and of hope deferred... the planet itself is groaning under the burden of pollution generated by a burgeoning human population that is augmented by religious imperatives and motivations.

In another perspective, Peters (2000: 11-26) submitted that:

.... Unbridling individual passions without regard to valuing human community let alone the ecosphere as a whole has led to a wanton pollution of our environment and the competition has put us on the brink of thermo-nuclear disaster....

The above statements show that the environment is heading for a catastrophic end if nothing is done to ameliorate the situation. This suggests that the environment is greatly ossified by several influences which perhaps are inimical to the general wellness of human kind and the society at large. It is in this perspective that this paper seeks to examine the effects of the environmental crises and the greenhouse issue in Nigeria. This will be done with our background of religious convictions in order to see how our religious institutions( particularly, Christianity) have 
fared in the face of this apparent crises that if care is not taken will snowballed into a major apocalypse for the entire nation. In doing this however, it will be apposite to examine key terms in the study in order to elicit a clearer understanding.

\section{Environment}

It is apt to remark that the term environment connotes different meanings and interpretations. It can be described as a place which surrounds a person at a particular time. This place influences the person's ideas and feelings, morally and psychologically. It is the "surrounding conditions which influence the growth and or development of an individual (Quirk, 1980:37). According to Oyewole (2003:368), the environment constitutes "the area of land inhabited by a people, including all that the land supports (plant and animal lives, water bodies both running and stagnant and the atmosphere overcastting that land).

In another perspective, the environment is considered to be more complex in nature and much more inclusive. It could be regarded as (the life-forms, flora, fauna and micro-organism) and the abiotic which can also be seen as both internal and external. It is further described from the ecological viewpoint as "the interactions between and among all the features above which affect the life and behaviour above which affect the life and behaviour of the inhabitants not just as individuals but also as a community of individuals" (Oyewole, 2003: 369).

Furthermore, it could also mean "environment for some creatures or collection of creatures, whether plants or animals". Hence, it is used to cover the entire natural world from ecosystem to biosphere that includes humans, plants, and animals (Connelly \& Smith, 1999). In the same vein, Umejesi (2006:6) describes the environment as "the system of abiotic, biotic and socio-economic components with which man interacts and at the same time to which he adopts and transforms and uses in order to satisfy his needs". Consequently, the environment could be regarded as an embodiment of both animate and inanimate beings which exist for the use of man. It could then be regarded as that which impacts the life of an organism or a group of organisms external to it.

\section{The Greenhouse Effect}

This refers to the way in which gases in the earth's atmosphere warm the earth like the glass roof of a greenhouse by letting sunlight in but keeping the reflected heat energy trapped inside. These naturally occurring gases, notably carbon dioxide and water vapour, are called greenhouse gases.

Intergovernmental Panel on Climate Change Fourth Assessment Report describes Green house effect as follows:

To balance the absorbed incoming [solar] energy, the Earth must, on average, radiate the same amount of energy back to space. Because the Earth is much colder than the Sun, it radiates at much longer wavelengths, primarily in the infrared part of the spectrum. Much of this thermal radiation emitted by the land and ocean is absorbed by the atmosphere, including clouds, and reradiated back to Earth. This is called the greenhouse effect.

The greenhouse effect is a process by which thermal radiation from a planetary surface is absorbed by atmospheric greenhouse gases and is re-radiated in all directions. Since part of this re-radiation is back towards the surface and the lower atmosphere, it results in an elevation of the average surface temperature above what it would be in the absence of the gases. Earth's natural greenhouse effect makes life as we know it possible. However, human activities, primarily the burning of fossil fuels and clearing of forests have intensified the natural greenhouse effect, causing global warming.

The "greenhouse effect" of the atmosphere is named by analogy to greenhouses which get warmer in sunlight, but the mechanism by which the atmosphere retains heat is different. A greenhouse works primarily by preventing absorbed heat from leaving the structure through convection, i.e. sensible heat transport. The greenhouse effect heats the earth because greenhouse gases absorb outgoing radiative energy and re-emit some of it back towards the earth (Shmaefsky, 2004).

The greenhouse effect has resulted in global warming which has had a negative impact on the society. Global warming denotes the accelerated warming of the earth surface due to anthropogenic (human activity related) release of greenhouse gases due to industrial activity and deforestation. According to Iyede (2009:119), "three major causes are considered responsible for global warming namely (1) variation of the earth's orbit around the sun (2) volcanic eruptions - emission of molten magma from the earth's crust. When these are emitted into the atmosphere, they caused increase in the atmospheric average temperature and (3) the atmospheric greenhouse gas concentration which mostly results from industrial activities. The effect of these has been colossal on man and his society. Consequently, environmental issues coupled with the greenhouse effect have heightened the rate of the ecological conditions, particularly in Nigeria. 
As such, in addressing the issue of global warming, the anthropogenic factor i.e. man's impact in nature becomes a matter of great concern. Global warming has been due extensively to depleting the ozone layer which also is traceable to human activities. The bottom line is the fact that mankind has been the brain behind most of the ecological and environmental problem confronting humanity as a whole. Having said this, it is salient to examine some of the environmental issues plaguing Nigeria.

\section{Environmental Issues/Problems in Nigeria}

Gaba- Waye (1997) remarked that:

The new millennium looks as if it is going to be one ridden with ecological crises as some contemporary scholars and environmentalists are drawing attention to serious damage the environment is undergoing.

This shows that the environment has changed considerably and this is having serious negative effect. In the same vein, Fasokun (2000: 24) opined that "progressive degradation of the earth's environment poses a threat to its very existence". This accounts for why environmentalists throughout the world continue to decry the abuse of the environment. In spite of this, the world has experienced and is still experiencing environmental degradation which orchestrates disasters throughout the world (Adelakun, 2009:221). The environmental problems arising from the Tsunami of December 2004, the massive heat wave in summer 2003 in Europe, the hurricanes and tornadoes in the USA, the floods in Nigeria and particularly the environmental pollution in the Niger Delta Area have resulted in colossal waste of lives and property. It is in this respect that the need has arisen for a better understanding of our environmental concerns by scientists and theologians alike and to stand against any form of environmental degradation by using every available channel to enlighten the public on the need for environmental friendliness and responsiveness. In this respect, we shall examine some of the environmental problems bothering Nigeria as a nation. This however, is not exhaustive as the list of the environmental problems is legion.

\section{Environmental Pollution}

This is a major environmental challenge in Nigeria. Pollution can be described as the introduction by man into the environment of substances and energy which are liable to cause hazard to human health, other living organisms resources and the ecological system. In another perspective, environmental pollution can be said to be human activities that could damage the structure or amenities of the environment and interfere with the legitimate use of the environment (Abodunrin, 2009:139).

Pollution is seen as one of the intractable problems affecting communities and urban centres particularly in Nigeria. Also, pollution poses a great challenge to the health of the people. Pollution can be classified into three broad categories vis-à-vis - land or surface area pollution, aquatic or water pollution and air or atmospheric pollution.

(a) Air Pollution: According to the World Health Organization (WHO: 1990) is limited to the situation in which the outer ambient atmosphere contains materials and concentrates which are harmful to man and the environment. In this situation, gaseous elements are released into the atmosphere in the form of solid and liquid particles and chemical pollutants like carbon-monoxide and other combustible elements. This brings about the greenhouse gases which are inimical to the environment.

(b) Water pollution: could be in the form of discharge of converted biological chemical and physical materials into water bodies. This may be in one or all of these forms: disposal of lubricating oil from machines and or automobiles into the river, international discharge of untreated toxic by-products by manufacturing industries into streams or rives and lastly, pollution occurring from crude oil and petroleum products into the river especially through pipeline vandalization and crude oil exploration. These have negative impacts on both the aquatic lives and people living in such communities.

(c) Land Pollution: could be regarded as the disposal of unwanted materials or waste on land. Examples of this is the waste product that often liter the land surface. The inabilities of people to properly dispose off their wastes have led to mounds of wastes generated by people especially in our urban centres. Dumping of refuse on water courses have been the cause of flooding in some parts of Nigeria. Notable is the Ogunpa flood in Oyo State. Lagos is not free from flooding as most houses are built on water-ways thereby preventing free flow of water.

\section{Deforestation}

This involves the large scale removal of forest, prior to its replacement by other land users. Deforestation may be distinguished from forest degradation which is a reduction in forest quality. The two are similar and result in several problems. They cause soil erosion and watershed destabilization, resulting in flooding or draught. They reduce biodiversity (the range of habitat, species, and genetic types) particularly significant in tropical forests which are homes for much of the world's biodiversity. Deforestation affects the livelihood of between 200 and 500 
million people who depend on forest for their food, shelter and fuel. Deforestation and degradation may contribute to regional and global climate imbalances. Forests play a major role in carbon storage, but with their removal, excessive carbon-dioxide in the atmosphere may lead to global warming, with many problematic side effects.

Deforestation processes are in general more destructive. Most forest soils in the tropics are far less fertile than temperate soils and are erodible. This is because high rainfall leaches out nutrients from the soil, preventing them from building up. Deforestation occur in response to policy, market and institutional "signals" these tend to "push" people into the forest, through difficult economic or social conditions outside orto "pull" people into the forest, through the attraction of profits (from logging, or forest clearance). Many policies effectively undervalue forests, such as low fees for logging or they over-value the benefits of removing forest for other uses which can be seen in the subsidization of flood prices. Some policies even require deforestation in order to show the owner has 'improved" the land. Also official debt, owed by many developing nations to industrialized countries, forces many developing nations into deforestation in order to generate foreign exchange.

While these are the root causes of deforestation, they are exacerbated by increasing population, increasing demands for forest products, and inappropriate technology. Reacting on the issue of deforestation, Olanisebe (2009:94) opines that:

There is the falling of trees in and around individual house. Majority of the forest reserves in Nigeria are being rampaged by those that could be described as "Marauders". They fell the trees unlawfully without planting another in return. Apart from depleting the country's economy, there is the problem of erosion that normally arises from such deforestation.

Consequently increasing numbers of human beings are encroaching on the remaining wild lands. Inestimable demands for energy are forcing the development of Aquatic regions of soil and gene and threatening the delicate ecological balance of the ecosystems and their wildlife. This tropical deforestation has already resulted in the extinction of as many as 750,000 species, and likely to eliminate millions if allowed to continue unchecked. This would mean the loss of a multiplicity of products, food, fibres, medical drugs, dyes, gums and resins. The challenges of deforestation are myriad.

\section{Overpopulation}

Overpopulation has negative implication as far as environmental issues are concerned. It is believed that while human population remained small and human technology modest, their impact on the environment was localized. However, as population increased and technology improved and expanded, more significant and widespread problems arose. With the industrial revolution, humans began in earnest to change the face to the earth, the nature of its atmosphere and the quality of the water. Today, unprecedented demands on the environment from a rapidly expanding human population and from advancing technology are causing a continuing and accelerating decline in the quality of the environment and its ability to sustain life.

Overpopulation brings about over-crowding particularly in towns and cities. Thus, Abogunrin (2009) remarks that:

In all our mega cities, all available lands are built up without any respect for environmental laws. Even in the new areas of our big cities, houses are built without any consideration for environmental hazards. Surprisingly, most of these buildings have government approved plans. It appears that those who approve these building plans have little or no consideration for environment hazards before approving the building plans.

Arising from this problem of over bloated population is the problem of food insecurity. On this note Abe (2009:29) retorts that:

Food insecurity threatens millions uncheck mated. Africa is bedeviled with chronic food insecurity which affects a great proportion of the population perhaps more than a quarter, in a fertile land flowing with milk and honey as its natural resources are concerned.

This presupposes that over population has a serious impact on social development index of the people. Overpopulation has also brought with it poor waste management system in many urban centres and this has led to contamination of fresh water sources. It has also led to lack of inadequate infrastructure in the society. Hence, the people have always been at the receiving end. 


\section{Urbanization}

It should be noted however, that the problem of urbanization arises from that of overpopulation as well as migration to cities and urban centres. As such, NEST (1992) remarks:

Environmental conditions in cities have gradually deteriorated due to the rapid growth of the cities and the attendant inability of social services and infrastructures to keep pace with the rate of growth. Inadequate storm drains, dumping of refuse in drainage liens and construction of houses close to and even on natural water channels have been shown to be responsible in that order for the increasing cases of flood in the urban centres. Environmental problems associated with the increasing growth of urban slums including overcrowding in squalid housing conditions, poor quality are unavailability of basic infrastructure and social services, such as water and sewage facilities and even lack of access routes.

These are some of the environmental challenges posed by urbanization. Urbanization remains one of the common causes of environmental degradation in Nigeria. The need to develop new cities has brought with it the use of land without consideration for ecological balance. As such, Northtcott (1996:30) remarks that:

Industrial activities in the third world cities tend to be much less carefully regulated than industrial activities in the first world. Hence, there are many ecological threats to land in the developing world.

\section{Oil Spillage}

This has been a major environmental challenge particularly in the Niger Delta and in other places through pipeline vandalization. It is a paradox that the Niger Delta which is the source of national revenue is an area synonymous with poverty, underdevelopment, unemployment, militancy, prostitution, disease and pollution. Oil product particularly, spillage has caused major damage to the ecosystem in the Niger Delta resulting in pollution and contamination of varying degree. Commenting on oil exploration in the Niger Delta, Omagu (2011) noted that:

The exploration and exploitation of oil have specific environmental hazards.

The drilling activities are land based, including the swampy areas. They cut the well formation, cushion them and use drilling mud, cement slurry and other acid stimulation are also used. The wastes from these sources are harmful to flora and fauna of the environment, including human being.

Spillage has been responsible for the destruction of aquatic lives which have been the mainstay of the economy in the area.

\section{The Response of the Church to the Environment Problems}

O Lord, how manifold are thy works!

In wisdom has thou made them all;

The earth is full of thy creatures.

Yonder is the sea, great and wide,

Which teems with things innumerable,

Living things both small and great. (Ps. 104:24f.)

Judaism and Christianity, the great faiths for which Abraham is an originary figure, are noted for separating humans from the surrounding ecosystems, for considering humans separate and special, created in the image of God. In one interpretation, humans are here partially to provide wise stewardship of nature; at the other extreme, nature is placed here for the pleasure of humans, to be used and discarded as needed.

This interpretation led Lynn White to write his often-cited 1967 essay, "Historical Roots of our Ecological Crisis," which linked Christianity to environmental degradation. White claims that "Christianity is the most anthropocentric religion in the world and has seen," that it "not only established a dualism of man and nature but also insisted that it is God's will that man exploit nature" (White, 1967:6). The most important source cited to support this is Genesis 1:28, which calls on man to "Be fruitful, multiply, fill the earth, and subdue it. Have dominion over the fish of the sea, over the birds of the sky, and over every living thing that moves on the earth." White does qualifies his argument, stating that "Christianity is a complex faith, and its consequences differ in differing contexts." He criticizes the Western European version of Christianity from the Renaissance onward, with its rationalistic view of science and technology, in combination with the Bible: "It was ceasing to be the decoding 
of the physical symbols of God's communication with man and was becoming the effort to understand God's mind by discovering how his creation operates" (White, 1967: 7). Decoupled from nature by the Bible, given the power of scientific domination, humanity has, in White's analysis, unleashed an increasing devastation upon the earth.

Many Christian thinkers have reacted sharply to White's allegation, believing that he —or at least his followers has misinterpreted a specific historical moment as a manifestation of Christianity's essence. They argue that a broader reading of Genesis calls for stewardship of God's creation, and that environmentalism is best considered an extension of Christian humility and the search for social justice. They also argued that it is unfair to take a single interpretation of one passage, that proclaiming man's dominion, as so central to Christianity's environmental message. Barbour, (1972:154) argues against the idea of a split between human and nature and calls for "rejection of the body-soul dualism of classical Christian thought and a return to the biblical view of man as a unitary being". Grizzle and Christopher (1996) further developed the idea of unity, calling for a humble anthropocentricism that conjoins economic, social justice and environmental needs. They emphasized the need to treat these as part of one body, metaphorically, the body of Christ and of the Church:

For the body does not consist of one member but of many. If the foot should say, 'Because I am not a hand, I do not belong to the body,' that would not make it any less a part of the body? But God has so composed the body, giving the greater honor to the inferior part, that there may be no discord in the body, but that the members may have the same care for one another (1 Corinthians 12:14-26).

A more recent Christian icon of environmentalism is Francis of Assissi, patron saint of animals. Born in 12th century Italy, Francis had pleasure preaching to birds and also believed to have freed many captive animals and to have tamed a wolf that had been menacing a town. Although Francis is a Catholic Saint, non-Catholics have shown great interest in his life and story. Qualifying his attack on Christianity, White argued that Christians could learn to live in harmony with the environment, if only they would emulate Saint Francis, who "proposed what he thought was an alternative Christian view of nature and man's relation to it; he tried to substitute the idea of the equality of all creatures, including man, for the idea of man's limitless rule of creation" (White, 1967: 10).Many Catholic thinkers disagreed with White, however, believing that Francis' story is essentially one of human redemption in which animals play a secondary role.

Having examined the environmental issues and problems confronting Nigeria, it is apposite to examine the response of the Church to these environmental issues. How has the Church fared in bringing about environmental change or preservation? How has the Church fared in bringing solace to a troubled world? In response to this question, we shall examine the Church's role from two main broad categories - the stewardship theory and the dominion theology.

\section{The Stewardship Theology}

This can be viewed from the perspective of Adam and Eve in the Garden of Eden. Both were given a commission to "till the ground" (Gen 2:15). This shows that man is regarded as a steward of what God has created and his responsibility lies in the fact that he is accountable to God with regard to the environment. According to Abogunrin (2009) "a careful reading of Gen1:26-31 reveals that far from instructing man to be a tyrant, he is to be a steward of the earth and of all other creatures". As a steward, man is seen as a co-worker with God and he is not a co-equal. Man is seen as a tenant and not as the owner and that he only holds the earth in trust for God and for the rest of creator, either present or yet to be born. This is because the authority given to man is only for a time and he should not be seen as usurping the power of God. Within this context therefore, the Church must understand that she is a steward as far as the environment is concerned.

\section{The Dominion Theology}

In contrast to the above is the view that man is given the mandate to have dominion over nature and to subdue it. Those in this category often refer to Gen.1:28.

Then God blessed then and God said to them, be fruitful and multiply, fill the earth and subdue it, have dominion over the fish of the sea, over the birds of the air and over everything that moves on the earth.

The perception of Christians and the Church in this category lies on the fact that the earth, environment or nature, is for man's sole instrumental use. His attitude here is exploitative in nature. As such, he goes all out to express this mandate "to subdue" and "to have dominion". Thus, according to Ayantayo (2009:330) "the anti-environment theologians interpret this passage to mean that God gives man freedom to do anything he wants to with the planet". 
The implication of this is that there may be chaos on the earth if everyone is at liberty to do as he wills with the environment. Therefore, Manus (2009:22) citing Okorodudu -Fabara opines that:

... the earth's natural resources were not given to man to "destroy", "pollute", or "degrade". It is reasonable inference therefore, that endowment of the earth's natural resources to man by the creator is intended for the advancement of the welfare of man towards this goal. Consequently, man's commission and empowerment to fill the earth and subdue it is nothing but a divine injunction to join in God's will for order and sustainability on earth (Manus: 2009:22).

It is however, pertinent that the Church in Nigerian should respond positively to the environmental challenges plaguing Nigeria as a nation. This can be achieved if the Church is not based on the Dominion theology.

It is important to state that in Nigeria today, the "Church business" seems to be a lucrative one and that is why virtually every empty space is now becoming a Church, not minding the environmental condition of such places. In addition, several Churches especially the white garments are located on water courses or near a river and this also may be environmentally unfriendly. A trip on the Lagos-Ibadan Express way is revealing. Virtually all the headquarters of Churches in Nigeria wants to have a portion of land to cite their place of worship along this route. As good as this is, it also constitute environmental hazard.

Strange enough, the Church is also involved in the issue of noise pollution through the megaphones blaring during each service. Ayantayo (2009: 334) opines that:

Christians need to live by examples starting with disengagement from noise pollution often associated with their liturgical activities and sitting of their churches.

The Church must recognize that the earth belongs to God and that we should do all things with moderation. In addition, street evangelism should be done with little or bearable noise. Also, citing of Churches within and around residential areas should be discouraged in order to guarantee peaceful coexistence. The Church should be responsive to the environmental challenges facing the community in which the Church is cited in order to give succor to a dying world.

\section{The Church and the Environment: The Way Forward}

There needs to be a paradigm shift in the way the Church perceives and understand the environment. This paradigm shift is necessary to accentuate the level of cooperation and sustainability of the environment particularly by the Church. In this regard, parochial sentiments should be done away with. Such sentiments that places too much emphasis on mere outward observances and relegates the need to be eco-friendly should be jettisoned. In this regard, the Dominion theology should be discountenanced because creation is one holistic enterprise and man is regarded as a steward in the whole picture.

There must be an attitudinal change orchestrated by a genuine desire for positive environmental outlook. This involves a respect and reverence for the environment which will in turn bring about a reverence for God. Thus, Dreibelbis (2005:6) puts it thus:

.... A respect for creation leads us to a reverence for God, and likewise, our reverence for God is reflected in our care for the creation.

Therefore, it is the responsibility of the Church to show case God through the environment thereby leading in the crusade for the care for the environment.

In another perceptive, all activities that degrade the environment and lead to extinction of species should be stopped. In doing this, the Church should not only fight against gas flaring and oil spillage, but should preach to their members, as well as government to legislate, enact and implement laws against environmental degradation by the oil industries. The type of sustainable society and developmentwhich the Church clamor for is the one in which people live with each other and their physical environment in ways that leads to continuing life rather than destruction. The Church and indeed all people must desist from practices that are destructive to the environment.

The Church which is an institution for ethical and moral teachings should be an advocate for a just and egalitarian society where people relate with each other and with the environment for the benefit of all. Therefore, the Church should call for the establishment of political and legal structures that will not only guarantee harmonious relationship between man and the eco-system, but will also stand as a vanguard against environmental degradation and the exploitation of the natural resources in ways that is limited to the social order. The Church should also 
demand for a sustainable society in which people regard the environment as part and parcel of life and as such, accord a measure of respect to the environment.

Omidiwura (2009:363) citing the pronouncement of the World Council of Churches (WCC) remarks that:

All members of God's earth are his creation and are to be treated responsibility. All of God's creation has values and is to be treated with reverence for the sake of its maker who accounted it good. We are commended to be good stewards of God's world. We are held responsible for it. It is not ours to do with them as we please; rather we are to keep it for the Lord.

By implication therefore, the Church should champion the cause of stewardship of the environment and be responsive towards having a sane environment and eco-system.

In the same vein, Ayantayo (2009) remarks:

In making the Church responsive and responsible to the Nigerian environment, the Church as a social cum moral community ought to have taken the lead in fostering good environment devoid of pollution.

It is in this perspective that the Church will be seen as performing and discharging its responsibility to humanity by providing a safer, cleaner and greener environment for humanity.

The government as well has a role to play in this regard. The government should stop playing lip service to environmental issues. They should do more than the annual tree planting exercise. Desert encroachment and desertification should be curtailed. Rather than flare gases, it should be domesticated for home use and this will reduce the greenhouse gases. Also government should take the issue of development with serious concern. Cities and towns should be well planned with adequate social infrastructure that will be congenial to people's social condition. The Niger Delta area should be revisited and the oil companies should have corporate social responsibilities to their host communities.

\section{Conclusion}

The issue of the environment and the greenhouse effect is a social concern for all humanity particularly, in Nigeria. It is a social issue. Therefore, it calls for serious concern from every individual, corporate bodies and government as well because of the dangers it pose to humanity. In addition, theologians and scientists are leaving no stone unturned in order to combat the impacts and the effects of these problems. Indeed, the environmental outlook for the future is taken with mixed feelings. In spite of the economic and political changes, interest in and concern for the environment remains high. The problems of acid deposition, chlorofluorocarbon, ozone depletion, heavy air pollution, gas flaring, toxic waste e.t.c still beg for solution and concerted action.

To reduce environmental degradation and for humanity to save its habitat, societies and people must recognize that the environment is finite. Humans must recognize that attacks on the environment threaten human survival. To this end, every citizen should be an agent of change and should take the advocacy seriously. The Church must rise up from the doldrums and take active part in this advocacy. We must all insist on having and maintaining good virtue for our society. The Church as well as the government should develop new and bold strategies so as to face the challenges against human and social conditions in order to checkmate the greenhouse effects on human life.

There is the need for general awareness among people at different strata of society. This awareness begins with education. Therefore, there is need for environmental awareness through education in schools-primary, post primarily and at the tertiary levels. Also curricula of these schools should include environmental discourses that will help in fighting the greenhouse effect thereby, bringing about a conducive environment for all to live in.

\section{References}

Abe, G. O. (2009). Biblical Bases for Environmental Concerns. In C. U. Manus (Ed.), Biblical Studies and Environmental Issues in Africa. A Publication of the Nigerian Association of Biblical Studies (NABIS) Western Zone; Ibadan: Alofe Press.

Abodunrin, A. O. (2009). Anti PollutionLaws according to Deut 23:13-14. In C. U. Manus (Ed.), Biblical Studies and Environmental Issues in Africa. A Publication of NABIS (Western Zone). Ibadan: Alofe Press.

Abogunrin, S. O. (2009). Biblical Studies and the Environment keynote Adebresi. In C. U. Manus (Ed.), Biblical Studies and Environmental Issues in Africa. A Publication of NABIS (Western Zone) Ibadan; Alofe Press. 
Adelakun, A. J. (2009). Thy Will be Done on Earth: A Re-reading of Matt. 6:10b and its implications for Nigeria on Environmental Issues. In C. U. Manus (Ed.), Biblical Studies and Environmental Issues in Africa. A Publication of NABIS (Western Zone). Ibadan: Alofe Press.

Ayantayo, J. K. (2009). Biblical Studies-Ethnical Evaluation of the Environment in Nigeria. In C. U. Manus (Ed.), Biblical Studies and Environmental Issues in Africa. A Publication of NABIS (Western Zone) Ibadan: Alofe Press.

Barbour, I. (1972). Attitudes toward Nature and Technology. In I. Barbour (Ed.), Earth Might Be Fair. New Jersey: Prentice Hall.

Connelly, J., \& Smith, G. (1999). Politics the Environment: From Theory to Practice. London/New York: Rutledge.

Dreibelbis, M. (2005). A Call to Christian Environmentalism.Revisions: A Journal of Christian Perspective, 1(2).

Fasokun, T. A. (2000). The Challenges of Adults Education (Series 139). ObafemiAwolowo University, Ile-Ife: O.A.U Press.

Gaye-Waye, A. (1997). Environmental Adult Education: A Factor in sustainable Development on the Eve of the third millelum. In H. Hinzer et al. (Eds), Adult Education and Development. Confintea V. institute for International Cooperation of the German Adult Education Association.

Grizzle, R., \& Christopher, B. (1996). The One Body of Christian Environmentalism.Christian Environmental Studies Center at Montreal College. Retrieved October 28, 2012, from http://cesc.montreat.edu/GSI/GSI-Conf/Mini-Grants/Taylor-OneBody.html

Iyede, M. O. (2009). Biblical contribution towards the solution of the problem of Global Warming according to Deut. 20:19-20. In C. U. Manus (Ed.), Biblical Studies and Environmental Issues in Africa. A Publication of NABIS (Western zone) Ibadan: Alofe Press.

Manus, C. U. (2003). Nature and Creation: Theology and Science in Dialogue. In P. A. Dopamuet et al. (Ed.), African Culture, Modern Science and Religions Thought. Ilorin: ACRS.

Nigeria Environment Study/Action Team (NEST). (1992). The Challenge of Sustainable Development in Nigeria. An NGO Report prepared for United Nations Conference on Environment and Development, Rio De-Janeiro, Brazil June 1-12.

Northcott, M. S. (1996). The Environment and Christian Ethics. Cambridge, UK: Cambridge University Press. http://dx.doi.org/10.1017/CBO9780511557477

Olanisebe, S. O. (2009). Revisiting creation Accounts in Gen 1-2 and the Dominion Theology in Relation to Environment in Nigeria. In C. U. Manus (Ed.), Biblical Studies and Environmental Issues in Africa. A Publication of NABIS (Western zone) Ibadan: Alofe Press.

Omidiwura, S. O. (2009). Biblical Doctrines and the Moreling of Environmental Pollution. In C. U. Manus (Ed.), Biblical Studies and Environmental Issues in Africa. A Publication of NABIS (Western zone) Ibadan: Alofe Press.

Omofonmwan, S. I., \& Osa-Edoh, G. I. (2009). The Challenges of Environmental Problem in Nigeria. Journal of Human Ecology, 23(1).

Oyewole, S. O. (2003). African Cultural Response to Ecological and Environmental Concerns. In P. A. Dopamu et al. (Eds.), African Culture, Modern Science and Religious Thought. Ilorin: ACRS

Peacocke, A. (1993). Foreword. In P. Hefner (Ed.), The Human Factor: Evolution, Culture and Religion. Minneapolis: Fortress Press.

Peters, T. (2000). God-The World's Future: Systematic Theology for a New Era. Minneapolis. Fortress Press.

Quirk, R. (1980). Longman Dictionary of Contemporary English. Britain: The Pitman Press.

Raufu, A. (2002). African under water: Nigeria's coastline is be signed by Global Warning. Environment Magazine. Retrieved from http://findarticules.com/p/articles/mi m1594

Sada, P. O., \& Odemerho, F. O. (Eds.). (1988). Environmental Issues and Management in Nigeria. Ibadan: Evans.

Shmaefsky, B. (2004). Favorite demonstrations for college science: an NSTA Press journals collection. NSTA Press. 
Umejesi, I. O. (2006).African Religion and Conservation of Nigeria's Environment of sustainable Development. A Paper presented at the Local Societies initiatives (LSI) and NASTRENS' Conference, University of Ilorin, $6^{\text {th }}-8^{\text {th }}$ March.

Watts, M. (2006). The Ellie Wiesel Foundation for Humanity, Commission of Nobel Laureates on Peace, Equality and Development in the Niger Delta Region of Nigeria. In M. Watts (Ed.), Curse of the Black Gold, Fifty Years of Oil on the Niger Delta. Brooklyn, New York: Power House Books.

White, L. (1967). Historical Roots of Our Ecological Crisis. Science, 155, 1203-1207. http://dx.doi.org/10.1126/science.155.3767.1203

\section{Copyrights}

Copyright for this articleis retained by the author(s), with first publication rights granted to the journal.

This is an open-access article distributed under the terms and conditions of the CreativeCommons Attribution license (http://creativecommons.org/licenses/by/3.0/). 